\title{
PENENTUAN INDUSTRI KERAJINAN SAPU SEBAGAI INDUSTRI UNGGULAN PRIORITAS KABUPATEN PURBALINGGA DAN PERMASALAHANNYA
}

\begin{tabular}{|c|c|}
\hline \multicolumn{2}{|c|}{$\begin{array}{c}\text { Oleh: } \\
\text { Evi Selvi } \\
\text { Universitas Singaperbangsa Karawang } \\
\text { pulma8003@gmail.com } \\
\text { DOI Artikel : https://doi.org/10.34308/eqien.v6i2.78 }\end{array}$} \\
\hline Article Info & Abstract \\
\hline $\begin{array}{l}\text { Article History: } \\
\text { Received 05 Agustus } 2019 \\
\text { Accepted } 19 \text { Agustus } 2019 \\
\text { Available Online 05 September } \\
2019\end{array}$ & $\begin{array}{l}\text { This article outlines the process of determining priority industries } \\
\text { based on the regulatory framework of industrial development } \\
\text { planning, starting at the national, provincial and district / city } \\
\text { levels, in accordance with the mandate of Law Number } 3 \text { of } 2014 \\
\text { concerning Industry. In the following description, the } \\
\text { determination of priority industries shows synchronization of } \\
\text { planning between regional centers. In the next section, this article } \\
\text { discusses the various problems faced by the Purbalingga broom } \\
\text { industry, as one of the priority industries selected in the } \\
\text { Purbalingga Regency industrial development plan. In the } \\
\text { concluding section, this article summarizes various general } \\
\text { problems faced by the Purbalingga broom industry, as well as } \\
\text { submitting suggestions for overcoming problems in the context of } \\
\text { developing the industry. }\end{array}$ \\
\hline 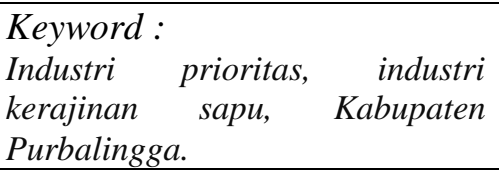 & \\
\hline
\end{tabular}

\section{PENDAHULUAN}

Purbalingga merupakan salah satu kabupaten di Provinsi Jawa Tengah yang memiliki sentra industri kerajinan sapu. Industri ini telah berperan dalam menciptakan nilai tambah sumber daya lokal, menyerap tenaga kerja dan meningkatkan pendapatan masyarakat (Sularso et al., 2014; Bappeda Kab. Purbalingga, 2012). Berdasarkan data Dinas Perindustrian Perdagangan dan Koperasi Kabupaten Purbalingga tahun 2014, jumlah produksi industri kerajinan sapu mencapai lebih dari 3,4 juta buah sapu per tahun, dengan nilai produksi per tahun mencapai lebih dari Rp 24 miliar. Pada tahun yang sama, nilai investasi yang telah ditanamkan pada industri ini sebesar Rp 1,02 miliar. Dari sisi penyerapan tenaga kerja, industri ini mempekerjakan sebanyak 705 orang, dengan jumlah industri mencapai 68 unit usaha.
Wilayah pemasaran produk-produk industri kerajinan sapu Purbalingga tidak hanya memasok untuk untuk pasar lokal, namun juga memasok daerah lain, seperti Jakarta, Bandung, Cirebon, Tasikmalaya, Semarang, Wonosobo, Banjarnegara, Surakarta dan sebagainya (Dinperindagkop Kab. Purbalingga, 2007; Sularso et al., 2014; Priswanto et al., 2017). Bahkan, produk-produk industri kerajinan sapu Purbalingga telah menembus pasar internasional, seperti Taiwan, Korea Selatan, Jepang, Malaysia, Thailand dan Amerika Serikat (Dinperindagkop Kab. Purbalingga, 2007; Sularso et al., 2014). Berdasarkan jenis bahan baku, industri kerajinan sapu Purbalingga memproduksi berbagai jenis sapu, seperti sapu gelagah, lidi, ijuk, rayang, dan hamada. Sedangkan berdasarkan jenis modelnya, produk-produk industri ini menghasilkan antara lain sapu kipas, sapu udang, sapu jengki, dan sapu model miring 
sebelah (Wulandari, 2014). Produk sapu yang saat ini sedang dikembangkan adalah produk kerajinan dari sabut kelapa (Kemenperin, 2016).

Besarnya potensi industri ini menjadikan industri kerajinan sapu termasuk ke dalam industri unggulan prioritas untuk dikembangkan. Namun demikian, industri kerajinan sapu menghadapi sejumlah permasalahan. Artikel ini berupaya untuk menguraikan proses penentuan industri prioritas sesuai kerangka peraturan perencanaan pembangunan industri di tingkat nasional sampai dengan tingkat daerah (provinsi dan kabupaten/kota). Selanjutnya, artikel ini membahas tentang berbagai permasalahan yang dihadapi oleh industri sapu Purbalingga. Pada bagian penutup, artikel ini meringkas berbagai permasalahan secara umum, serta menyampaikan saran untuk mengatasi permasalahan-permasalahan dalam rangka pengembangan industri ini.

\section{KAJIAN PUSTAKA DAN PEGEMBANGAN HIPOTESIS Industri Prioritas Nasional dalam Rencana Induk Pembangunan Industri Nasional (RIPIN)}

Undang-undang Nomor 3 Tahun 2014 tentang Perindustrian telah meletakkan industri sebagai salah satu pilar ekonomi dan memberikan peran yang cukup besar kepada pemerintah dan pemerintah daerah untuk mendorong kemajuan industri nasional secara terencana. Peran tersebut diperlukan dalam mengarahkan perekonomian nasional untuk tumbuh lebih cepat dan mengejar ketertinggalan dari negara lain yang lebih dahulu maju.

Tatanan dan segala kegiatan yang bertalian dengan kegiatan industri diselenggarakan dengan tujuan: (1) mewujudkan industri nasional sebagai pilar dan penggerak perekonomian nasional; (2) mewujudkan kedalaman dan kekuatan struktur industri; (3) mewujudkan industri yang mandiri, berdaya saing, dan maju, serta industri hijau; (4) mewujudkan kepastian berusaha, persaingan yang sehat, serta mencegah pemusatan atau penguasaan industri oleh satu kelompok atau perseorangan yang merugikan masyarakat; (5) membuka kesempatan berusaha dan perluasan kesempatan kerja; (6) mewujudkan pemerataan pembangunan industri ke seluruh wilayah Indonesia guna memperkuat dan memperkukuh ketahanan nasional; dan (7) meningkatkan kemakmuran dan kesejahteraan masyarakat secara berkeadilan.

Untuk memperkuat dan memperjelas peran pemerintah dalam pembangunan industri nasional, perencanaan pembangunan industri nasional yang sistematis, komprehensif, dan futuristik disusun dalam wujud RIPIN. Berdasarkan undang-undang di atas, RIPIN merupakan pedoman bagi pemerintah dan pelaku industri dalam perencanaan dan pembangunan Industri. RIPIN 2015-2035 menetapkan 10 (sepuluh) industri prioritas yang dikelompokkan ke dalam industri andalan, industri pendukung, dan industri hulu. Berbagai industri prioritas yang masuk ke dalam kelompok industri andalan adalah (1) industri pangan, (2) industri farmasi, kosmetik dan alat kesehatan, (3) industri tekstil, kulit, alas kaki dan aneka, (4) industri alat transportasi, (5) industri elektronika dan telematika, dan (6) industri pembangkit energi. Sedangkan industri prioritas yang masuk ke dalam kelompok industri pendukung adalah industri barang modal, komponen, bahan penolong dan jasa industri. Sementara itu, industri-industri prioritas yang masuk ke dalam kelompok industri hulu adalah (1) industri hulu agro, (2) industri logam dasar dan bahan galian bukan logam, (3) industri kimia dasar berbasis migas dan batubara.

Penentuan berbagai industri prioritas di atas dalam RIPIN 2015-2035 didasarkan pada pertimbangan-pertimbangan, seperti (1) memenuhi kebutuhan dalam negeri dan substitusi impor, atau memiliki potensi pasar yang tumbuh pesat di dalam negeri; (2) meningkatkan kuantitas dan kualitas penyerapan tenaga kerja, atau berpotensi dan/atau mampu menciptakan lapangan kerja produktif; (3) memiliki daya saing internasional, atau memiliki potensi untuk tumbuh dan bersaing di pasar global; (4) memberikan nilai tambah yang tumbuh progresif di dalam negeri, atau memiliki potensi untuk tumbuh pesat dalam kemandirian; (5) memperkuat, memperdalam, dan menyehatkan struktur industri; dan (6) memiliki keunggulan komparatif, penguasaan bahan baku, dan teknologi. Di samping itu, penentuan industriindustri prioritas tersebut didasarkan untuk (1) memperkokoh konektivitas ekonomi nasional; (2) menopang ketahanan pangan, kesehatan dan energi; dan (3) mendorong penyebaran dan pemerataan industri. 
Industri Unggulan Provinsi dalam Rencana Pembangunan Industri Provinsi (RPIP)

Undang-undang Nomor 3 Tahun 2014 tentang Perindustrian telah mengatur penyelenggaran urusan pemerintahan di bidang perindustrian oleh pemerintah, pemerintah daerah provinsi, dan pemerintah daerah kabupaten/kota, baik secara bersama-sama maupun sesuai dengan kewenangan masing-masing. Dalam undangundang tersebut, setiap gubernur wajib menyusun RPIP, dengan mengacu pada RIPIN dan Kebijakan Industri Nasional (KIN) dalam tataran pelaksanaannya. Pemerintah Provinsi Jawa Tengah telah menyusun RPIP, dengan terbitnya Peraturan Daerah Nomor 10 Tahun 2017 tentang Rencana Pembangunan Industri Provinsi Jawa Tengah Tahun 2017-2037. Dalam RPIP tersebut tercantum visi pembangunan industri Provinsi Jawa Tengah 2017-2037 adalah "Terwujudnya Industri Jawa Tengah yang Berdaya Saing dan Berkesinambungan".

Berdasarkan RPIP Jawa Tengah 2017-2037, ditetapkan Industri Unggulan Provinsi (IUP) Jawa Tengah sebagai berikut:

1. Industri pertambangan dan penggalian lainnya;

2. Industri makanan;

3. Industri minuman;

4. Industri pengolahan tembakau;

5. Industri tekstil;

6. Industri pakaian jadi;

7. Industri kulit, barang dari kulit dan alas kaki;

8. Industri kayu, barang dari kayu dan gabus (tidak termasuk furnitur) dan

9. barang anyaman dari bambu, rotan dan sejenisnya;

10. Industri produk batu bara dan pengilangan minyak bumi;

11. Industri bahan kimia dan barang dari bahan kimia;

12. Industri farmasi, produk obat kimia dan obat tradisional;

13. Industri logam dasar;

14. Industri komputer, barang elektronika dan optik;

15. Industri kendaraan bermotor, trailer dan semi trailer;

16. Industri alat angkutan lainnya;

17. Industri furnitur;

18. Industri pengolahan lainnya; dan

19. Industri piranti lunak dan konten multimedia.
Penetapan industri unggulan di atas didasarkan pada 3 (tiga) kriteria pokok yang selanjutnya ditetapkan 10 (sepuluh) sub-kriteria atau faktor. Tiga kriteria pokok tersebut adalah

a. Kriteria keunggulan; mencakup faktor pemasaran, ketersediaan dan kontinuitas bahan baku, dukungan sumber daya manusia, dukungan kebijakan dan kelembagaan pemerintah;

b. Kriteria manfaat; mencakup faktor nilai tambah ekonomi, nilai tambah sosial dan prestise/kekhasan daerah; dan

c. Kriteria penerimaan stakeholders; mencakup faktor kesiapan dan kesediaan masyarakat, pemerintah dan pelaku usaha.

Sedangkan 10 (sepuluh) sub-kriteria yang ditetapkan berdasarkan berbagai kriteria di atas adalah

a. nilai tambah ekonomis/peningkatan pendapatan daerah;

b. nilai tambah sosial/penyerapan tenaga kerja dan peningkatan

c. kesejahteraan;

d. ketersediaan dan kontinuitas bahan baku/dukungan sumber daya

e. alam;

f. aspek pemasaran/akses dan volume pasar;

g. dukungan kebijakan dan kelembagaan pemerintah;

h. dukungan sumber daya manusia;

i. kekhasan daerah;

j. kesiapan dan kesediaan masyarakat;

k. kesiapan dan kesediaan pemerintah; dan

1. kesiapan dan kesediaan pelaku usaha.

Selain itu, penetapan IUP juga mempertimbangkan beberapa kriteria di antaranya:

a. identifikasi potensi daerah;

b. daftar industri prioritas nasional berdasarkan RIPIN;

c. usulan industri prioritas Jawa Tengah berbasis sinkronisasi potensi daerah dengan industri prioritas nasional dalam RIPIN dan pertimbangan aspek strategis pengembangan industri Jawa Tengah.

\section{Industri Unggulan Prioritas dalam Rencana Pembangunan Industri Kabupaten (RPIK)}

Dalam Undang-undang Nomor 3 Tahun 2014 tentang Perindustrian diuraikan bahwa setiap bupati/walikota wajib menyusun Rencana Pembangunan Industri Kabupaten/Kota, dengan mengacu pada RIPIN dan KIN. RPIK disusun dengan paling sedikit memperhatikan: 
a. potensi sumber daya Industri daerah;

b. Rencana Tata Ruang Wilayah Provinsi dan Rencana Tata Ruang Wilayah Kabupaten/Kota; dan

c. keserasian dan keseimbangan dengan kegiatan sosial ekonomi serta daya dukung lingkungan.

Berdasarkan Kemenperin RI (2016), industri kerajinan sapu termasuk industri unggulan prioritas dalam rancangan RPIK Kabupaten Purbalingga . Penentuan industri unggulan prioritas dalam RPIK Kabupaten Purbalingga harus mengacu pada RPIP Jawa Tengah, sebagaimana diamanatkan dalam Peraturan Daerah Nomor 10 Tahun 2017 tentang Rencana Pembangunan Industri Provinsi Jawa Tengah Tahun 2017-2037 pasal 2(b). Sesuai RPIP Jawa Tengah 2017-2037, industri kerajinan sapu termasuk dalam kelompok IUP, yaitu Industri Kayu, Barang dari Kayu dan Gabus (Tidak Termasuk Furnitur) dan Barang Anyaman dari Bambu, Rotan dan sejenisnya, dengan jenis industrinya adalah Industri Barang Anyaman dari Bambu, Rotan dan sejenisnya.

\section{METODE PENELITIAN}

Dalam rangka pengembangan industri kerajinan sapu di Kabupaten Purbalingga, dapat diidentifikasi berbagai permasalahan secara menyeluruh. Identifikasi dilakukan dengan menggunakan Analisis Strengths Weaknesses Opportunities Threats (SWOT). Berdasarkan Kemenperin RI (2016), sejumlah kekuatan, kelemahan, peluang dan ancaman dalam pengembangan industri kerajinan sapu di Kabupaten Purbalingga dapat dilihat pada tabel berikut

\section{HASIL DAN PEMBAHASAN}

\section{Tabel 1}

Tabel SWOT

\begin{tabular}{|c|c|}
\hline gths) & Weaknesses) \\
\hline $\begin{array}{l}\text { A. Aspek Bahan Baku } \\
\text { - Bahan baku gelagah } \\
\text { unik, berbeda dengan } \\
\text { barang sejenis yang } \\
\text { dihasilkan di daerah } \\
\text { lain (misalnya } \\
\text { Kabupaten } \\
\text { Wonosobo); } \\
\text { - Lahan tanaman } \\
\text { gelagah luas; } \\
\text { - Tanaman gelagah } \\
\text { ramah lingkungan, } \\
\text { karena dapat menahan } \\
\text { erosi tanah. }\end{array}$ & $\begin{array}{l}\text { A. Aspek Bahan Baku } \\
\text { - } \text { Ketersediaan bahan } \\
\text { baku gelagah } \\
\text { dipengaruhi faktor } \\
\text { musiman (panen); } \\
\text { - } \text { Harga bahan baku } \\
\text { gelagah berfluktuasi; } \\
\text { - } \text { Ketersediaan bahan } \\
\text { baku ditentukan oleh } \\
\text { para pengepul besar di } \\
\text { tingkat hulu; } \\
\text { - } \text { Bahan baku gelagah } \\
\text { asal Purbalingga juga } \\
\text { dipasok untuk }\end{array}$ \\
\hline
\end{tabular}

\begin{tabular}{|c|c|}
\hline 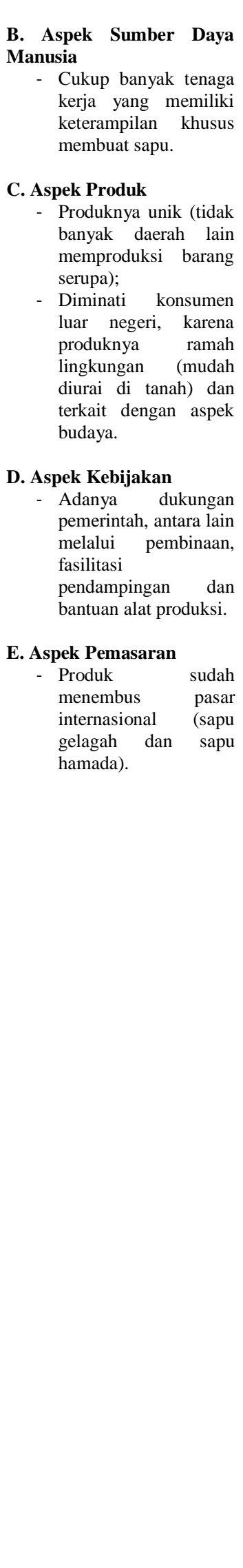 & 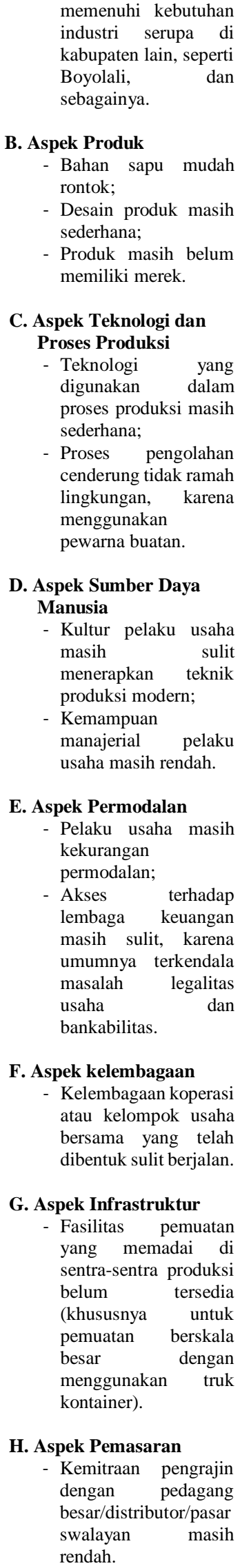 \\
\hline
\end{tabular}




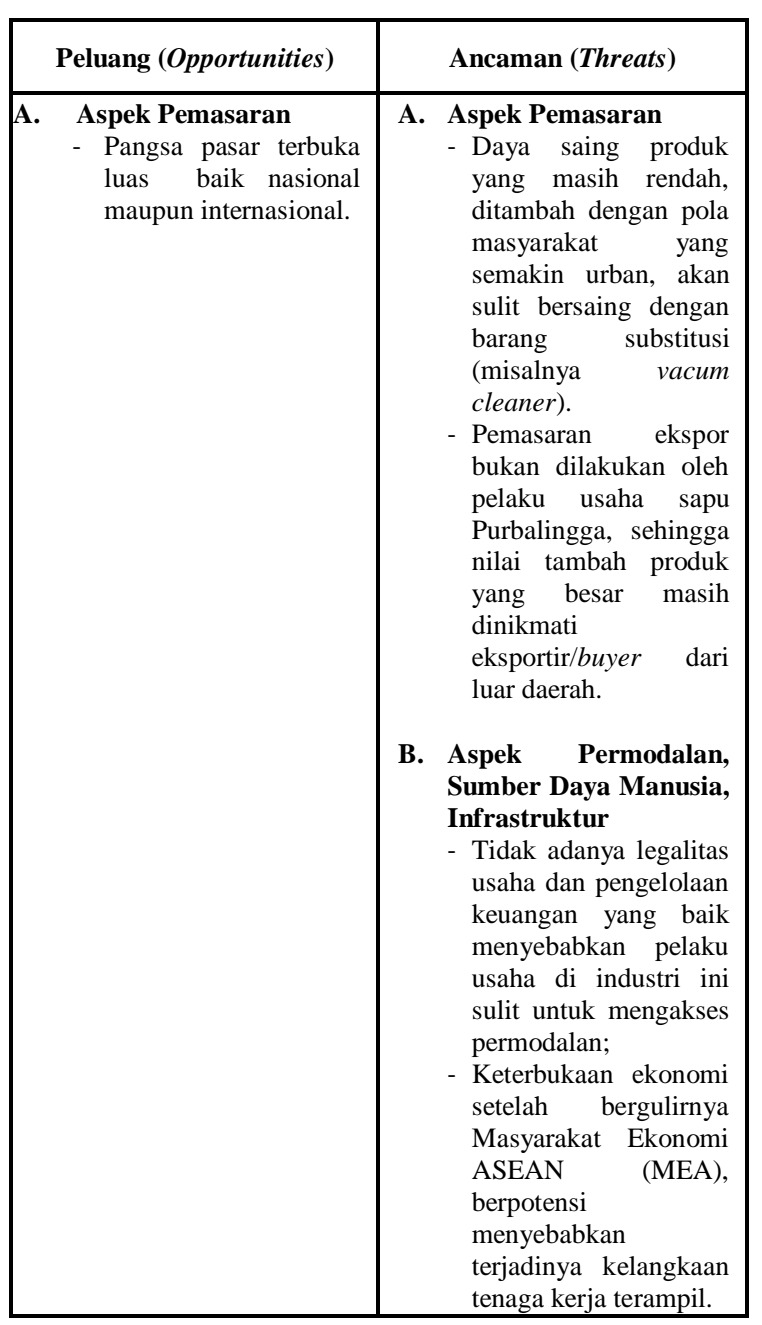

\section{SIMPULAN DAN SARAN}

Berdasarkan hasil analisis di atas bahwa Pengembangan industri kerajinan sapu sebagai industri unggulan prioritas Kabupaten Purbalingga sampai saat ini masih berhadapan dengan berbagai permasalahan. Secara umum, permasalahan-permasalahan yang dihadapi adalah (1) kapasitas produksi yang belum memenuhi permintaan pasar; (2) kemampuan menghasilkan produk yang berkualitas; (3) kemampuan manajemen pengelolaan usaha yang belum profesional dan keterbatasan terhadap akses terhadap pendanaan; (4) kemampuan pemasaran produk yang masih perlu ditingkatkan; dan (5) kemampuan branding dan sertifikasi produk untuk pasar modern.

Untuk mengatasi berbagai permasalahan di atas, disarankan untuk:

a. memiliki alat produksi yang tepat guna, didukung permodalan yang memadai dan tersedia tenaga kerja trampil sesuai kebutuhan;

b. memiliki sertifikasi produk;

c. memiliki manajemen usaha profesional bagi pelaku usaha;

d. memiliki kemampuan mengakses pendanaan permodalan;

e. memiliki sumber daya manusia pemasaran yang kompeten;

f. ikut serta dalam pameran; dan

g. produk sapu purbalingga memiliki branding dan sertifikasi untuk meningkatkan daya saing di pasar modern.

\section{REFERENSI}

[Bappeda Kab. Purbalingga] Badan Perencanaan Pembangunan Daerah Kabupaten Purbalingga. (2012): Analisa Produk Domestik Regional Bruto Kabupaten Purbalingga 2011.

[Dinperindagkop Kab. Purbalingga] Dinas Perindustrian Perdagangan dan Koperasi Kabupaten Purbalingga. (2007): Profil Sentra Industri Potensial Kabupaten Purbalingga Tahun 2007.

[Kemenperin RI] Kementerian Perindustrian. (2016): Penyusunan Rencana Pembangunan Industri Kabupaten Purbalingga, Jakarta: Direktorat Pengembangan Perwilayahan Industri.

Pemerintah Republik Indonesia. (2015): Peraturan Pemerintah Republik Indonesia Nomor 14 Tahun 2015 Tentang Rencana Induk Pembangunan Industri Nasional Tahun 2015-2035, Tersedia pada http://www.kemenperin.go.id/ripin.p df. Diakses pada tanggal 28 September 2018.

Pemerintah Provinsi Jawa Tengah. (2017): Peraturan Daerah Provinsi Jawa Tengah Nomor 10 Tahun 2017 Tentang Rencana Pembangunan Industri Provinsi Jawa Tengah Tahun 2017-2037, Tersedia pada http://jdihukum.jatengprov.go.id/do wnload/produk_hukum/perda/perda tahun_2017/perda_10_th_2017.pdf. 
Diakses pada pada tanggal 28 September 2018.

Republik Indonesia. (2014): Undang-undang Republik Indonesia Nomor 3 Tahun 2014 tentang Perindustrian, Tersedia pada http://www.kemenperin.go.id/downl oad/5181/Undang-Undang-No-3-

Tahun-2014-Perindustrian. Diakses pada tanggal 25 September 2018.

Priswanto, Supriyanti, R., Murdyantoro, E. (2017): Peningkatan Produktivitas dan Efisiensi UKM Sapu Glagah di Kabupaten Purbalingga dengan Pemanfaatan Teknologi. Prosiding Seminar Nasional dan Call for Papers: "Pengembangan Sumber Daya Perdesaan dan Kearifan Lokal
Berkelanjutan VII”. 2017 Nov 17-18; Purwokerto.

Sularso, K.E., Satriani, R., Hidayat, N. (2014): Analisis finansial pembuatan sapu glagah di Kabupaten Purbalingga: studi kasus pada industri kecil sapu glagah, Agrin, 18(2), 118-128.

Wulandari, A.P. (2014): Pemberdayaan masyarakat desa dalam upaya peningkatan kesejahteraan keluarga melalui pelatihan pembuatan sapu gelagah di Desa Kajongan Kecamatan Bojongsari Kabupaten Purbalingga [skripsi], Yogyakarta: Program Studi Pendidikan Luar Sekolah Jurusan Pendidikan Luar Sekolah Fakultas Ilmu Pendidikan Universitas Negeri Yogyakarta. 